Little weeds
$\begin{aligned} & \text { Experiment casts } \\ & \text { doubt on effects } \\ & \text { of transgene flow } \\ & p 462\end{aligned}$

\title{
Gates ploughs millions into plan for assault on killer diseases
}

\section{Declan Butler, Paris}

Microsoft founder Bill Gates is to provide US\$200 million for basic biological research into the treatment and control of killer diseases such as malaria and tuberculosis.

The initiative, a partnership between the Bill \& Melinda Gates Foundation in Seattle, Washington, and the US National Institutes of Health (NIH), will establish several large consortia to research diseases that kill millions of people in poor countries, but which are often neglected by biomedical research programmes in rich countries.

Gates announced the Grand Challenges in Global Health initiative on 26 January at the World Economic Forum's annual meeting in Davos, Switzerland. It will support about ten large collaborative projects, costing some \$20 million each. Likely targets include work to exploit the recently sequenced genome of the human malaria parasite Plasmodium falciparum (M. J. Gardner et al. Nature 419,498-511;2002), and the closer study of natural mechanisms that block the development of full-blown tuberculosis in many people who carry the disease.

The initiative will be administered through the Foundation for the National Institutes of Health, a charity set up in 1996 to help the NIH to collaborate with outside philanthropies and industry. Its scientific programme will be steered by a board chaired by Harold Varmus, former director of the NIH and president of the Memorial SloanKettering Cancer Center in New York. The star-studded board also includes Richard Klausner, former head of the US National Cancer Institute and now executive director of the Gates Foundation's global health programme; Anthony Fauci, director of the US National Institute of Allergy and Infectious Diseases, and Elias Zerhouni, the current NIH director.

Zerhouni says that the initiative will support "high-risk, high-impact science" and complement the NIH's main funding vehicle of investigator-initiated grants. The idea, he says, is to attract top scientists from around the world, including more from the $\mathrm{NIH}$, to global health.

"There are not enough top-flight scientists committed to global health at the fundamental science level," Zerhouni says. The foundation's freedom to fund overseas

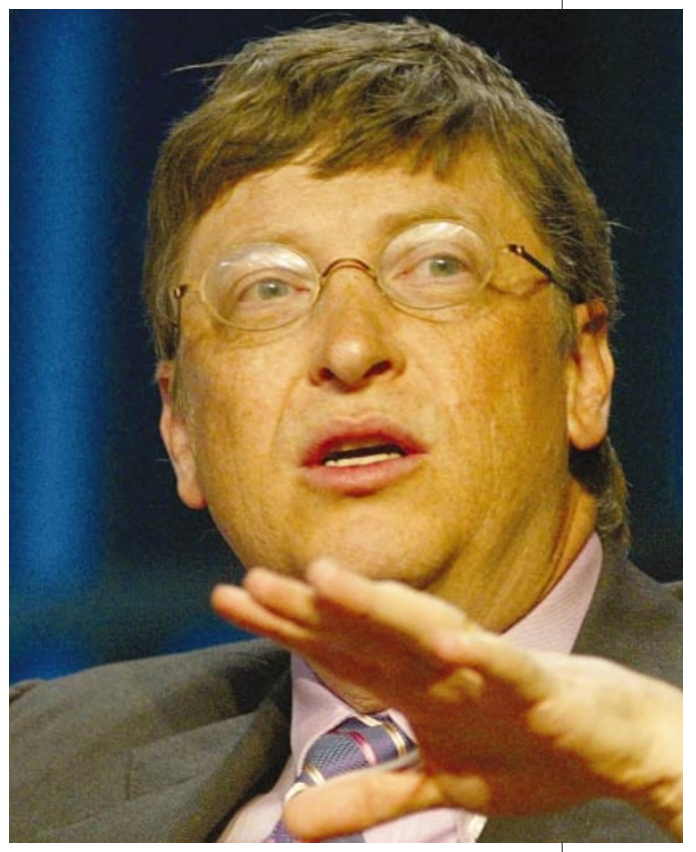

Bill Gates wants to redress the funding imbalance against research into poor countries' diseases.

\section{UK cell biologist takes pole position at Rockefeller}

\section{Erika Check, Washington}

Paul Nurse, the head of Britain's largest cancer-research organization, is crossing the Atlantic to take charge of Rockefeller University in New York.

Rockefeller announced the appointment of Nurse, a cell biologist, as its new president on 24 January. Nurse plans to take up the position full-time in November, and says that he intends to focus on developing the university's ability to do interdisciplinary and translational research.

"Rockefeller has tremendous strengths, particularly in cell biology and aspects of organismal biology and neurobiology," Nurse says. "And it has a high-quality research hospital, which allows you to explore how all this fantastic biology can

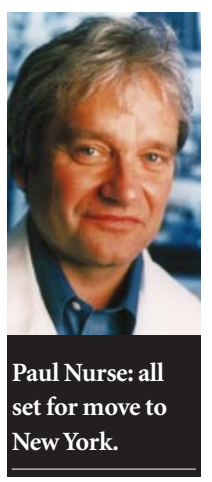

lead to new therapies." The Manhattan-based institution is unique among major US research universities in having no undergraduate students or departments, but instead operating 70 fairly autonomous laboratories.

Previous presidents of Rockefeller have had a bumpy ride. The last president, Arnold Levine, left last February after a strange public encounter with a graduate student (see Nature 415, 721; 2002). And back in 1991, David Baltimore had to resign over his handling of a case of alleged scientific misconduct involving a co-worker.

Nurse, who won a Nobel prize in 2001 for his work on the cell cycle, led one of Britain's main cancer charities, the Imperial Cancer Research Fund, into its merger last year with the Cancer Research Campaign to create Cancer Research UK, which he has since run.

"Paul Nurse has the stature befitting a Rockefeller president," says David Ho, an AIDS researcher at Rockefeller's Aaron Diamond AIDS Research Center. "He's had so much background experience leading the cancer effort in the UK - and he has tremendous scientific credibility."

Nurse has never worked full-time in the United States. "Many researchers go to work in other countries early in their career," he says. "I'm just doing it at the end of mine." 
is also "a potential means to enlarge our research mission internationally”, he says.

Jacquelline Fuller, a spokeswoman for the Gates Foundation, says that the initiative will soon embrace other partners to make it truly international in scope. To this end, the foundation is in discussions with the London School of Hygiene and Tropical Medicine, where Gates has already contributed $\$ 40$ million to a malaria research centre, and the British researchfunding charity the Wellcome Trust.

Gates sees the initiative as a starting point in tackling a huge imbalance whereby less than $10 \%$ of the $\$ 70$-billion annual world spend on medical research goes on the diseases that cause $90 \%$ of illness and death. "There is great potential for science and technology to solve persistent global health challenges, but far greater resources are needed," he says.

Existing global expenditure on malaria research is estimated to be just $\$ 100$ million annually, and the Special Programme for Research and Training in Tropical Diseases run by the United Nations and the World Bank has only $\$ 30$ million a year to cover ten major tropical diseases.

Impressive as it, the Gates grant is small beer next to the $\$ 1.5$ billion that the World Health Organization has said is needed annually to support a Global Health Research Fund dealing with major killer diseases. But Francis Nkrumah, director of the Noguchi Memorial Institute for Medical Research at the University of Ghana and the only African on the board of the new initiative, says it marks a major step towards that goal. He thinks that it will help to forge a consensus among biologists on the most promising research avenues, and hence attract further private and public research funds. "This is a beacon of hope for Africa," he says.

www.gatesfoundation.org

\section{Transgenic crop trial's gene flow turns weeds into wimps}

\section{David Adam, Amsterdam}

Could 'superweeds' carrying genes from genetically modified crops behave less like Superman and more like Clark Kent, his puny alter ego? The first results from a pioneering field trial in the United States suggest as much - and that the effects of gene flow from transgenic crops may be less aggressive than some environmentalists predict.

The experiment, run by Neal Stewart and his colleagues at the University of Tennessee, Knoxville, would have struggled to win regulatory approval in Europe. In it the team used an oilseed rape crop that had been given a gene from the bacterium Bacillus thuringiensis $(B t)$, enabling it to produce a toxin that repels insects. They crossed the genetically modified variety with a wild relative, Brassica rapa, then backcrossed the resulting hybrid with the wild plant again, and released the resulting 'superweed' into the environment.

The resistant weed's ability to compete as a pest - and therefore the likelihood of the rogue gene sweeping through wild plant populations - was assessed by its effect on fields of wheat. In other fields, the researchers introduced naturally occurring weeds.

The team found that the transgenic weed was far from dominant, having 20\% less effect on wheat yield than the unmodified B. rapa weeds. Stewart presented his team's results, from the first year of trials in North Carolina and Georgia, at a conference on gene flow between plants held in Amsterdam on 21-24 January.

Stewart, who believes that genetically modified crops are currently "over-regulated", suggests that the modified weeds lose potency because they are disrupted by the genetic load

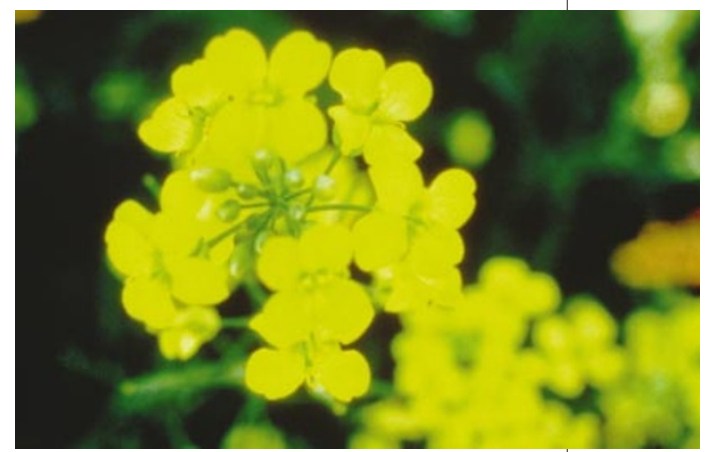

Early trial results suggest that gene flow from transgenic crops puts weeds at a disadvantage.

of crop genes being carried over with the $B t$ transgene. "Weeds have undergone years of selection that make them very good at what they do,"he says.

Other plant researchers welcomed the results as an important advance. "We need to move on from asking whether gene flow takes place, to investigating what happens when and where it does," says Brian Johnson, biotechnology adviser to the conservation group English Nature and an expert on transgenic-crop issues.

But some cautioned that the preliminary results are not a green light for the use of such crops in Europe, where their commercial planting is under a de facto moratorium. In a separate study announced last year, plant ecologist Allison Snow at Ohio State University in Columbus found that similar Bt transgenes can make wild sunflowers produce more seeds - a sign that modified wild populations could prosper and spread in the environment (see Nature 419, 655; 2002).

\section{Head of Spanish lab network quits over lack of funds}

\section{Monica Salomone, Madrid}

The president of Spain's main network of scientific research laboratories has resigned, complaining that the government gave him neither the resources nor the autonomy he needed to do the job.

Theoretical physicist Rolf Tarrach, who ran the CSIC research council for two-anda-half years, says that he will leave his post within a few weeks, once he has helped the government to select his successor.

Spanish science minister Josep Piqué confirmed the news, saying that Tarrach "had expressed his wish to go back to his research a long time ago".

At the CSIC, Tarrach was responsible for
120 laboratories, which employ about 2,200 researchers. But he often complained about the lack of funding and human resources. "I could do very little of what I intended" in the position, he says.

In a letter to the science ministry last October, Tarrach had asked to be replaced if certain measures were not taken. He wanted to see salaries for CSIC researchers rise by $7-10 \%$ to match those of university researchers. "The best researchers won't go to the CSIC" unless this happens, he says. “Decisions about the CSIC's policy that used to be taken by its presidency are now taken at the ministry," he adds. "This makes it very difficult to run a modern institution."
Tarrach says that his requests were ignored, so he filed his resignation two weeks ago and will now return to his academic post at the University of Barcelona.

The resignation has yet to be announced publicly. This, says Tarrach, is to avoid "interference" with the storm of criticism currently lashing the Spanish government over its handling of the ecological disaster caused by the sinking of the tanker Prestige (see Nature 420, 347; 2002).

One possible candidate to replace Tarrach is Emilio Lora-Tamayo, a physicist who is currently vice-president of the CSIC and head of a commission advising the government on its response to the Prestige oil spill. 